J. MED. MICROBIOL. - VOL. 16 (1983) $443-457$

(C) 1983 The Pathological Society of Great Britain and Ireland

\title{
IMMUNOGENIC AND PROTECTIVE PROPERTIES OF MENINGOCOCCAL SEROTYPE 2a PROTEIN IN THE HEN-EMBRYO MODEL
}

\author{
F. E. Ashton, J. A. Ryan, B. B. Diena and C. E. Frasch* \\ Bureau of Microbiology, Laboratory Centre for Disease Control, Ottawa, Canada \\ K1A OL2 and *Bureau of Biologics, Food and Drug Administration, Bethesda, MD \\ 20014, USA
}

\begin{abstract}
SUMmaRY. The ability of serotype 2 outer membrane protein (SP-2) of Neisseria meningitidis strain M986 serogroup B, serotype 2a (B, 2a) to stimulate antibody formation in hens and to confer protection against meningococcal challenge to embryos from immunised hens was investigated. Hens, housed with roosters, were immunised with $100 \mu \mathrm{g}$ of SP-2 once a week for 5 weeks to maintain consistent levels of serum antibody during the study. Antibodies in sera of hens, yolks and plasma of 13-day-old embryos reacted in enzyme-linked immunosorbent assays and immunodiffusion with outer membrane vesicles (OMV) from serotypes $2 \mathrm{a}, 2 \mathrm{~b}$ and $2 \mathrm{c}$ and most of the other prototype group $\mathrm{B}$ strains of $N$. meningitidis. Cross-reactivity of hen sera with most OMV appeared after only one injection of SP-2. Embryos from immunised hens were protected against challenge with up to 10,000 LD50 doses of either the homologous strain M986 (B, 2a) or strain M1011 (B, 2a). Protection was also evident against strains 614 (W135, 2a), S5896(Y, 2c) and $2241(\mathrm{C}, 2 \mathrm{a})$, but not against strain 78704 (C, 2a) despite strong cross-reactivity of antibody with OMV of this strain. Embryos were only partially protected against strain 78069 (B, 2b) and were fully susceptible to strain 2996 (B, 2b). Some protection was also obtained against meningococcal strains M1080 (B, 1), M982 (B, 9), S3032 (B, 12), 79001 (B, 12), 79694 (B, 15-related) but not strain 77252 (B, nontypable). These results suggest that proteins extracted from both serotype $2 \mathrm{a}$ and $2 \mathrm{~b}$ meningococci would provide the broadest protection against infection with group B, serotype 2 meningococci and that antibody, presumably directed against common peptides in the major outer membrane proteins, can prevent infection by some other disease-associated serotypes of $N$. meningitidis.
\end{abstract}

\section{INTRODUCTION}

Neisseria meningitidis serogroup B is responsible for a large proportion of meningococcal disease in the world (Farries et al., 1975; The Meningococcal Disease 
Surveillance Group, 1976; Bovre et al., 1977; Holten, 1979; Varughese and Acres, 1980). Unfortunately, group B capsular polysaccharide is not immunogenic in man (Wyle et al., 1972); consequently meningococcal non-capsular cell surface antigens including protein and complexes of protein and group B polysaccharide are being investigated as possible vaccines against disease caused by group B meningococci (Zollinger et al., 1978; Frasch, 1979; Zollinger et al., 1979; Frasch et al., 1982).

Serotyping based on the specificity of protein and lipopolysaccharide antigens in the outer membrane vesicles (OMV) of $N$. meningitidis has been useful for identifying non-capsular antigens that may be potential immunising agents (Frasch and Chapman, 1972a and $b$; Zollinger and Mandrell, 1977). Serotype 2 protein was chosen as a component of a group B polysaccharide-protein complex because of the involvement of serotype 2 meningococci in meningococcal disease (Gold et al., 1971; Frasch and Chapman, 1973; Munford, Patton and Gorman, 1975; Jones and Tobin, 1976; Frasch, 1977; Frasch and Friedman, 1977; Ashton et al., 1980; Poolman, Hopman and Zanen, 1980; DeMaeyer, Seba and Reginster, 1981). Serotype 2 meningococci have been divided into serotypes 2a, 2b, and 2c (Poolman et al., 1980) and there appears to be an important relationship between serotype $2 \mathrm{~b}$ and group $\mathrm{B}$ disease (Ashton et al., 1980; Poolman et al., 1980). Therefore, it is important to determine the ability of protein extracted from a serotype 2 a strain of $N$. meningitidis to protect against infection with meningococci of serotypes $2 \mathrm{a}, 2 \mathrm{~b}$ and $2 \mathrm{c}$.

In this study, a hen-embryo model (Diena et al., 1976, 1978 $a$ and $b$ ) was used to investigate the ability of protein extracted from the group $\mathrm{B}$, serotype 2a $N$. meningitidis strain M986 to stimulate antibody formation in hens and to protect embryos obtained from immunised hens against challenge with homologous and heterologous serotypes of $N$. meningitidis.

\section{MATERIALS AND METHODS}

Strains and growth conditions. The group B prototype strains 1-15 were characterised by Frasch and Chapman (1972a). The prototype 2b and 2c strains 2996 and 3459 were kindly provided by J. Poolman, University of Amsterdam, The Netherlands and strain S5896 by H. Feldman, Upstate Medical Centre, Syracuse, NY. Other strains were from the culture collection of the National Reference Centre for Neisseria, Ottawa. The serogroup, serotype and LD50 for chicken embryos of each strain are summarised in table I. The serogroup and serotype are designated by a letter and number respectively in parentheses after each strain number, e.g., strain M1011, serogroup B, serotype 2a is indicated as M1011 (B, 2a). Unless otherwise stated all organisms were grown on GC medium base (Oxoid) containing defined supplement $1 \%$ and ferric nitrate $0.001 \%$ (Kellogg et al., 1963) for $18 \mathrm{~h}$ at $36^{\circ} \mathrm{C}$ in the presence of $\mathrm{CO}_{2} 5 \%$.

Identification of serogroup and serotype. Strains of $N$. meningitidis were serogrouped by slide agglutination (Ashton et al., 1979) and the antiserum agar method (Craven et al., 1978; Ashton, Ryan and Diena, 1980). Serotyping was performed by agar gel double diffusion with antisera prepared against the prototype group B strains 1-15 and OMV prepared from the various strains (Ashton et al., 1980). The protein content of OMV was determined by the method of Lowry et al. (1951). Serotype 2a, 2b, and 2c strains were identified as described by Poolman et al. (1980) with absorbed anti-M1011 (2a), anti-2996 (2b) and anti-3459 (2c) sera.

Vaccine. Serotype 2 protein (Lot DO-6, termed SP-2) was prepared from OMV of a non-encapsulated variant of the prototype strain M986 grown in trypticase soy broth (Frasch and Robbins, 1978). The OMV were treated with deoxycholate (Sigma Chemical Co., St Louis, MO.) to dissolve the lipopolysaccharide (LPS). The vaccine was analysed chemically as described previously (Frasch and Robbins, 1978). Outer membrane protein patterns were 
TABLE 1

Characteristics of $N$. meningitidis strains used to challenge chicken embryos

\begin{tabular}{|c|c|c|c|c|}
\hline Strain & Source & Serogroup & Serotype & LD50* \\
\hline M986 & prototype-F $\dagger$ & B & $2 a$ & $<10$ \\
\hline M1011 & prototype-F† & B & $2 a$ & $<10$ \\
\hline 2241 & blood & $\mathrm{C}$ & $2 a$ & $<10$ \\
\hline 78704 & CSF & C & $2 a$ & $<10$ \\
\hline 614 & vagina & W135 & $2 a$ & $<10$ \\
\hline 2996 & prototype-P $\ddagger$ & B & $2 b$ & $<10$ \\
\hline 78069 & CSF & B & $2 b$ & $<10$ \\
\hline S5896 & & $\mathrm{Y}$ & $2 c$ & $<10$ \\
\hline M1080 & prototype-F $\dagger$ & B & 1 & $<10$ \\
\hline M982 & prototype-F† & B & 9 & $<10$ \\
\hline 79001 & $\mathrm{CSF}$ & B & 12 & 50 \\
\hline S3032 & prototype-F† & B & 12 & 500 \\
\hline $79694 \S$ & CSF & B & 15 & $<10$ \\
\hline $77252^{\circ}$ & $\mathrm{CSF}$ & B & nontypable & $<10$ \\
\hline
\end{tabular}

\footnotetext{
* Expressed as cfu; LD50 determined with 13-day-old embryos obtained from nonimmunised hens.

$\dagger$ Prototype group B strains of Frasch and Chapman (1972a).

$\$$ Prototype serotype 2 b strain described by Poolman et al. (1980).

$\S$ Formed a precipitin band of partial immunological identity with anti- 15 serum and considered to be serotype 15-related.
}

determined by sodium dodecyl sulphate polyacrylamide gel electrophoresis (SDS-PAGE; Frasch and Gotschlich, 1974).

Immunisation of hens with SP-2. Leghorn hens were purchased locally and fed on a diet free from antibiotics. Three groups of 17-20 hens were housed with two roosters per group. Preimmunisation blood samples were obtained from all hens. Hens belonging to groups I and II were immunised intravenously (i.v.) via the medial wing vein with $100 \mu \mathrm{g}$ of SP-2, once a week for 5 consecutive weeks. Blood was collected from six hens from each group by cardiac puncture 1 , $2,3,4,5,6,9$ and 12 weeks after the initial injection of SP-2. The same hens were chosen for bleeding on each occasion. In addition, all hens in groups I and II were bled on the third and sixth weeks respectively after initial injection. Hens in group III were used as a source of control eggs. Sera were allowed to separate from blood clots for $4 \mathrm{~h}$ at $40^{\circ} \mathrm{C}$, and were removed and stored at $-20^{\circ} \mathrm{C}$ until used. Eggs were collected daily from unimmunised and immunised hens commencing 7 days after initial injection. Eggs collected during one week were stored at $4^{\circ} \mathrm{C}$, and then incubated simultaneously at $37^{\circ} \mathrm{C}$ and $20 \%$ humidity in a Brower incubator (Brower Manufacturing Co., Quincy, IL).

Enzyme-linked immunosorbent assay (ELISA). Microassays were performed with the buffers described previously (Frasch, 1977). The OMV $(0.2 \mathrm{ml}$ volumes) at a protein concentration of $20 \mu \mathrm{g} / \mathrm{ml}$ in $0.1 \mathrm{M} \mathrm{Tris,} p \mathrm{H} \mathrm{8.5}$, were adsorbed on to the wells of E.I.A. microtitration plates (Linbro Division, Flow Laboratories Inc., Hamden, $\mathrm{CN}$ ) for $18 \mathrm{~h}$ at room temperature. The contents of the wells were aspirated and the plates washed three times with Sorensen's phosphate buffered saline, $p \mathrm{H} 7.2$ containing bovine albumin (Fraction V, Sigma) $0.1 \%$ and Brij $350 \cdot 1 \%$ (PBAB). The plates containing the same buffer were incubated for $1 \mathrm{~h}$ at $37^{\circ} \mathrm{C}$ and the buffer was then aspirated. Hen sera and yolks and plasma of embryos were diluted in PBAB and $0.2 \mathrm{ml}$ of each dilution was transferred to appropriate wells of the OMV-coated plates. The plates were incubated for $1 \mathrm{~h}$ at $37^{\circ} \mathrm{C}$. The contents of the wells were aspirated and the plates washed three times with PBAB. Alkaline phosphatase conjugated rabbit anti-chicken IgG (heavy and light chains; ZYMED Laboratories, Burlinge, CA) was diluted 1 in 3000 in PBAB and $0.2 \mathrm{ml}$ added to each well. The plates were incubated at $37^{\circ} \mathrm{C}$ for $1 \mathrm{~h}$, washed three times with saline containing bovine albumin $0.1 \%$ and Brij $350.1 \%$ and $0.2 \mathrm{ml}$ of a solution of nitrophenol phosphate (Sigma) $1 \mathrm{mg} / \mathrm{ml}$ in $0.1 \mathrm{M}$ Tris- $\mathrm{HCl}, p \mathrm{H} 9.8$ added to each well. The plates were left at room temperature for $30 \mathrm{~min}$. Extinction at $405 \mathrm{~nm}\left(\mathrm{E}_{405}\right)$ was read with a Titertek Multiscan (Flow Laboratories, Missassauga, Ontario). The $\mathrm{E}_{405}$ that would have been attained 
if the reaction had proceeded for $60 \mathrm{~min}$ was calculated. Results of each assay were corrected by an internal standard consisting of a pool of three sera obtained from hens immunised with SP-2. ELISA was also performed as described above with group B prototype rabbit sera to ensure that OMV were binding to the solid phase. Goat anti-rabbit IgG conjugated to alkaline phosphatase (heavy and light chains, Miles Laboratories Inc., Elkhart, IN) was used at a dilution of 1 in $\mathbf{4 0 0 0 .}$

Agar gel double diffusion with hen sera and yolks of embryos was performed as described for serotyping with the exception that the agar contained sodium chloride $8 \%$ (Munoz, 1971).

Meningococcal challenge of chicken embryos. Thirteen-day-old embryos were used in this study because preliminary experiments indicated that better protection was obtained with embryos that had developed for 13 rather than 12 days. Cultures of meningococci on GC medium were harvested after growth for $18 \mathrm{~h}$ and suspended in Dulbecco's phosphate buffered saline, $p \mathrm{H} 7 \cdot 2$, containing gelatin $0.1 \%$ (DPBG) and the suspensions adjusted to an $\mathrm{E}_{504} 0.0 .5$ with a Bausch and Lomb Spectronic 20 spectrophotometer. Appropriate challenge dilutions were prepared with DPBG. The number of cfu of meningococci was determined by viable counts on the final challenge dilution made for each experiment. Viable counts between 100-200 cfu were expressed to the nearest $25 \mathrm{cfu}$. Challenge doses containing greater numbers of organisms were estimated according to the dilutions made. Eight to 10 embryos were given i.v. injections of $0.05 \mathrm{ml}$ of the appropriate bacterial dilution. Eggs were candled daily for 3 days and deaths recorded.

\section{RESULTS}

\section{Analysis of vaccine}

SP-2 contained $<10 \%$ LPS and $<1 \%$ sialic acid and nucleic acid. The SDS-PAGE profile was similar to that published previously (Frasch and Robbins, 1978 ) and indicated that $>50 \%$ of the vaccine consisted of the class $2(41 \mathrm{~K})$ protein. Class $1(46 \mathrm{~K})$ and class $5(32 \mathrm{~K})$ proteins were present in small amounts.

\section{Antibody response of hens to SP-2 determined by ELISA}

A preliminary study (data not given) was performed to determine the immune response of hens to an injection of SP-2 followed by a booster injection 2 weeks later. Low levels of antibody were present 2 weeks after the first injection. A second injection of $100 \mu \mathrm{g}$ of SP-2 2 weeks after the initial dose resulted in a two- to three-fold increase in serum antibody which persisted for approximately 2 weeks and began to decline by the third week. Strong cross-reacting antibody was present against OMV of strains M982 (B, 9), M136 (B, 11), S3032 (B, 12), BC-4 (B, 13), S3446 (B, 14) and $355 \mathrm{H}(\mathrm{B}, 15)$ but less or no cross-reacting antibody was found against OMV of strains M1080 (B, 1), M981 (B, 4), M992 (B, 6) and M978 (B, 8).

The rapid decline in serum antibody did not permit the collection of a sufficient number of eggs to perform the desired number of challenge experiments. Therefore, in order to maintain persistent serum antibody levels for a longer period, hens were immunised once a week for 5 consecutive weeks with $100 \mu \mathrm{g}$ of SP-2. The immune response of hens bled at various intervals during a 12-week period after immunisation is shown in fig. 1. A rapid rise of serum antibody to strain M986 (B, 2a) occurred in hens, reached a maximum after 5 weeks and declined rapidly when antigenic stimulation ceased. Cross-reacting antibody against strain S3032 was present (fig. 1b). Similar antibody responses were obtained against strains M982 (B, 9), M136 (B, 


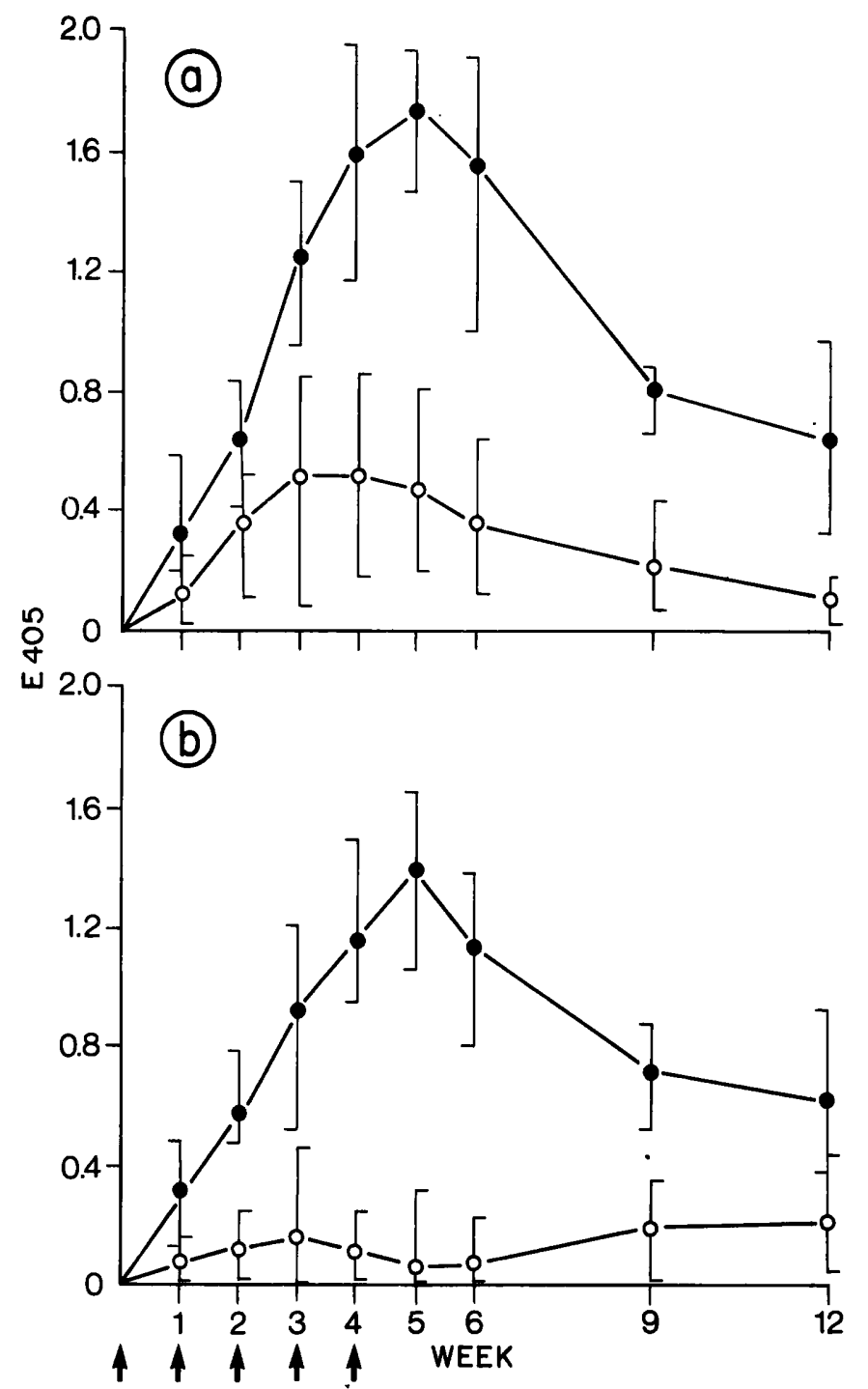

FIG. 1.-Serum antibody response of hens immunised with five consecutive weekly injections of $100 \mu \mathrm{g}$ of SP-2. Arrows indicate when injections were given. Antibody against OMV was measured by ELISA. (a) $-\bullet$, OMV-M986(B,2a); O- O, OMV-M981(B,4). (b) $\bullet-\bullet$, OMV-S3032(B,12);

11), BC-4 (B, 13), S3446 (B, 14) and 355H (B, 15). Moderate cross-reactivity was obtained against strains M981 (B, 4) (fig. 1a), M1080 (B, 1), and M978 (B, 8) and little antibody activity was detected against strains M992 (B, 5) (fig. 1b), M990 (B, 6) and 77252 (B, NT).

The mean ELISA values for sera from 17 hens (group I) and 19 hens (group II) bled 3 and 6 weeks respectively after initial injection of SP-2 are shown in table II. All hens produced antibody to the homologous OMV. The ELISA values were higher with OMV from serotype $2 a$ meningococci than with that from either serotype $2 b$ or 
TABLE II

Antibodies detected by ELISA in sera of hens immunised with SP-2 and in yolks and plasma of eggs obtained from immunised hens

\begin{tabular}{|c|c|c|c|c|}
\hline \multirow{3}{*}{$\begin{array}{l}\text { OMV from } \\
\text { strain }\end{array}$} & \multicolumn{4}{|c|}{ Mean (range) $\mathrm{E}_{405}$ value at $60 \mathrm{~min}$ obtained with } \\
\hline & \multicolumn{2}{|c|}{ Sera (diluted 1 in 2000) from } & \multirow[b]{2}{*}{ Yolks $\dagger$} & \multirow{2}{*}{$\begin{array}{c}\text { Plasma from } \\
\text { embryos } \ddagger\end{array}$} \\
\hline & Group I hens* & Group II hens* & & \\
\hline M986(B,2a) & $1.54(0.09-2.00)$ & $1.64(1 \cdot 18-2 \cdot 00)$ & $1.88(1.66-2.00)$ & $0.88(0.66-1.02)$ \\
\hline M1011(B,2a) & $1 \cdot 14(0 \cdot 22-1 \cdot 62)$ & $1.08(0.24-1.42)$ & $1.30(0.74-1.44)$ & \\
\hline $2241(\mathrm{C}, 2 \mathrm{a})$ & $1.20(0 \cdot 30-2 \cdot 00)$ & $1 \cdot 10(0 \cdot 76-1 \cdot 74)$ & $1.42(1.08-1 \cdot 74)$ & $0.60 \S$ \\
\hline $78704(\mathrm{C}, 2 \mathrm{a})$ & $1.60(0.60-2.00)$ & $1.48(1.01-1.92)$ & $1.64(1.46-1.84)$ & $0.72 \S$ \\
\hline $614(\mathrm{~W} 135,2 \mathrm{a})$ & $1.02(0.36-1.74)$ & $0.76(0 \cdot 40-1 \cdot 26)$ & $1 \cdot 10(1.02-1.48)$ & \\
\hline $2996(\mathrm{~B}, 2 \mathrm{~b})$ & $0.80(0.26$ & $0.70(0.24-1.32)$ & $0.87(0.75-1.46)$ & $0.64 \S$ \\
\hline $78069(\mathrm{~B}, 2 \mathrm{~b})$ & $0.58(0 \cdot 16$ & $0.46(0.14-0.92)$ & $0.74(0.60-1.06)$ & \\
\hline $6(Y, 2 c)$ & $0.56(0.20$ & $0.54(0.22-0.82)$ & $0.74(0.50-1.00)$ & \\
\hline $80(\mathrm{~B}, 1)$ & $0.56(0.00-0.55)$ & $0.50(0.10-0.84)$ & $0.80(0.44-1 \cdot 12)$ & $0.90(0.76-$ \\
\hline & $1.08(0.60-1.80)$ & $0.88(0.14-1.62)$ & $1.32(0.84-1.75)$ & $0.90(0.6$ \\
\hline 12) & $1.28(0 \cdot 80-1.95)$ & $1.24(0.44-1.96)$ & $1.74(1 \cdot 18-1.96)$ & $1 \cdot 00(0 \cdot 92-1 \cdot 24)$ \\
\hline & & $1.06(0.38-1.44)$ & $\ldots$ & \\
\hline 796 & & $1.16(0.52-1.62)$ & & \\
\hline & $1.04(0.52-2.00)$ & $1 \cdot 04(0 \cdot 30-1 \cdot 64)$ & $1.24(0 \cdot 70-1 \cdot 66)$ & $0 \cdot 76(0.48-1 \cdot 0$ \\
\hline & $0 \cdot 18(0 \cdot 00-0 \cdot 54)$ & $0.30(0.00-0.74)$ & $0 \cdot 24(0 \cdot 14-0 \cdot 38)$ & $0 \cdot 18(0 \cdot 12-0 \cdot 24)$ \\
\hline
\end{tabular}

* Group I sera were collected 3 weeks after the first injection and group II sera after 6 weeks. Values represent the mean of 17 sera for group I and 19 sera for group II. Preimmune sera gave E405 values $<0 \cdot 10$. † Yolks were diluted 1 in 500; values represent the mean of four yolks. Yolks from normal eggs gave E405 values $<0 \cdot 10$.

$\ddagger$ Plasma from embryos was diluted 1 in 50 . Values represent the mean of four plasma samples. Plasma from normal eggs gave $\mathrm{E}_{405}$ values $<0 \cdot 10$.

$\S$ Value obtained with a pool of four samples of plasma.

serotype $2 \mathrm{c}$ meningococci. The hen sera also cross-reacted strongly with OMV of the heterologous serotype strains M982 (B, 9), S3032 (B, 12), 79001 (B, 12), 79694 (B, 15) and $355 \mathrm{H}(\mathrm{B}, 15)$, moderately with OMV of strain M1080 (B, 1) and only slightly with OMV of strain 77252 (B, NT). The mean ELISA values of yolks and plasma of 13-day-old embryos are also shown in table II. The eggs were laid 8 weeks after the initial injection or 3 weeks after the fifth injection of protein. Generally, yolks and plasma contained antibody to the same OMV as hen sera.

\section{Agar gel double diffusion}

Fig. 2 shows the results of immunodiffusion when a serum collected before immunisation (preimmune) and five randomly selected immune hen sera were reacted with a lithium acetate extract of the homologous strain M986 (B, 2a). The preimmune serum (well 1) failed to react but the immune sera (wells 2-6) formed precipitin bands of immunological identity with the extract.

Fig. 3 illustrates the reactions of serum from an immune hen and egg yolk with OMV from serotype $2 \mathrm{a}, 2 \mathrm{~b}$, and $2 \mathrm{c}$ strains of $N$. meningitidis. The serum (left) and yolk (right) formed precipitin bands of immunological identity with serotype 2a strains M986, 2241, and 78704 (wells 1, 2, and 3) and precipitin bands of partial identity with serotype 2c strain S5896 (well 4) and serotype 2b strains 78069 and 2996 (wells 5 and 6).

Fig. 4 shows the results of immunodiffusion when serum from an immune hen and 


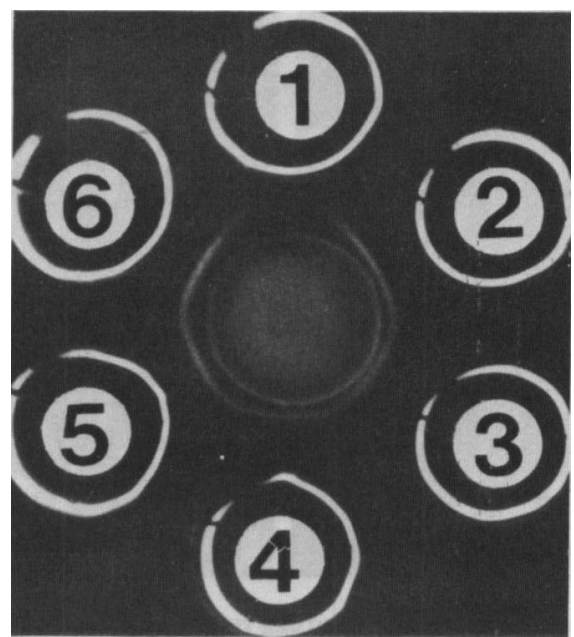

FIG. 2.-Agar gel double diffusion of hen sera against a lithium acetate extract of $N$. meningitidis strain M986(B,2a). The central well contained the extract. Well 1 contained preimmune hen serum; wells 2-6 contained sera from five hens collected 7 days after the fifth immunisation with SP-2. Diffusion was allowed to proceed for 5 days.

egg yolk were reacted with OMV from serotype 2a strains M986 and M1011 (wells 1 and 2) and some other heterologous serotypes used to challenge the embryos. The serum (left) and yolk (right) formed strong precipitin bands with the serotype 2a strain M1011 (well 2) and also with strains M1080 (B, 1), 79001 (B, 12) and 79764 (B, 15) (wells 3,5 , and 6 respectively) and a weak precipitin band with strain 77252 (B, NT) (well 4).

Protection of 13-day-old embryos against challenge with N. meningitidis. Embryos collected at various intervals during the immunisation programme were challenged
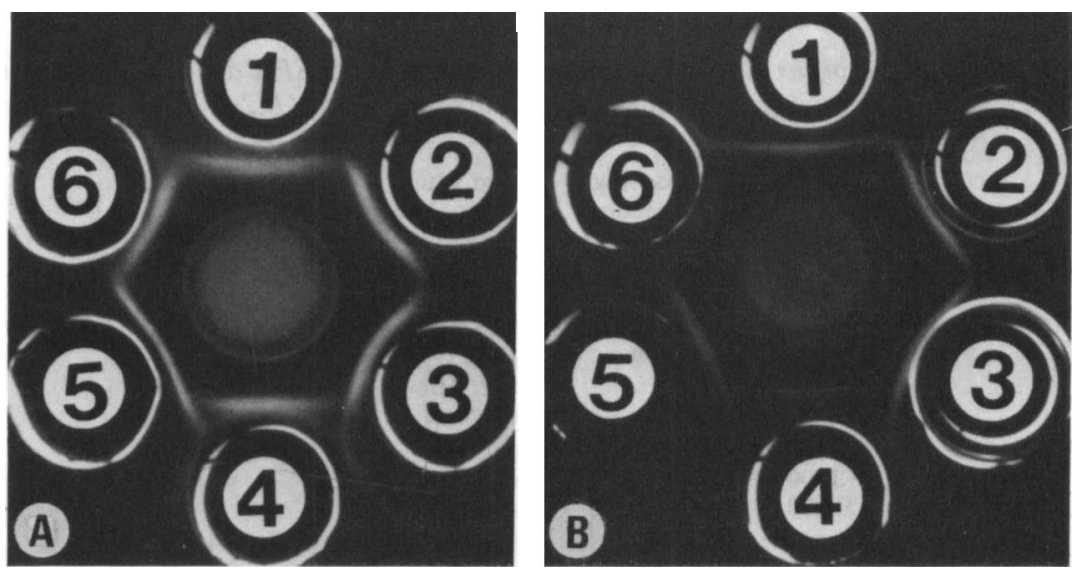

FIG. 3.-Agar gel double diffusion of hen serum and egg yolk against $O M V$ of serotype $2 \mathrm{a}, 2 \mathrm{~b}$ and $2 \mathrm{c}$ strains of $N$. meningitidis. A. The central well contained hen serum obtained 7 days after the fifth injection of SP-2. B. The central well contained yolk obtained from an egg laid 21 days after the fifth injection. Peripheral wells contained OMV of serotype 2 strains: (1) M986(B,2a), (2) 2241(C,2a), (3) $78704(C, 2 a)$, (4) S5896(Y,2c), (5) 2996(B,2b), (6) 78069(B,2b). Diffusion was allowed to proceed for 6 days. 

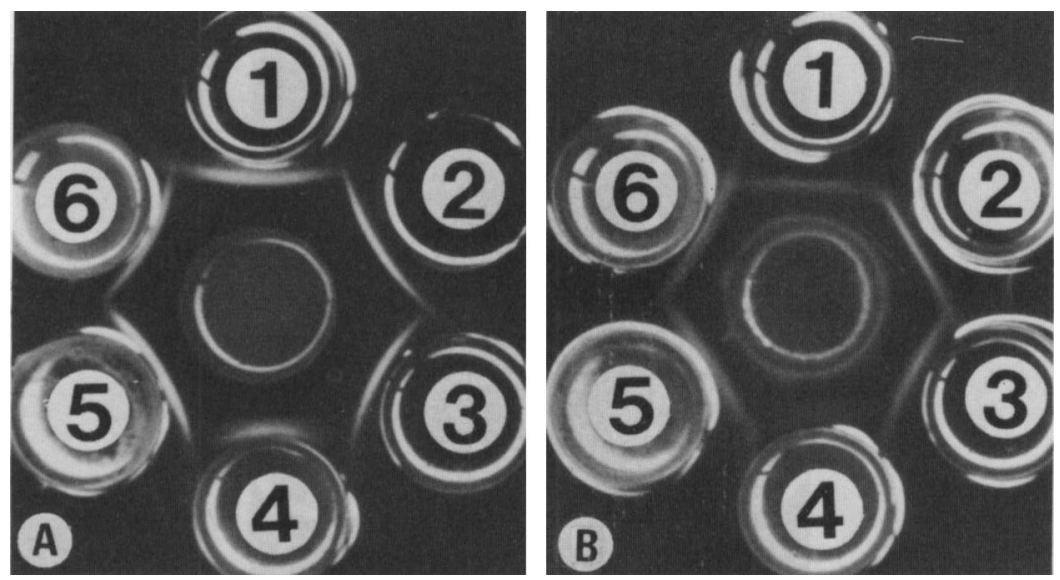

FIG. 4.-Agar gel double diffusion of hen serum and egg yolk against OMV of some heterologous serotypes of $N$. meningitidis. A. The central well contained hen serum obtained 7 days after the fifth injection of SP-2. B. The central well contained yolk obtained from an egg laid 21 days after the fifth injection of SP-2. Peripheral wells contain OMV of meningococcal strains: (1) M986(B,2a), (2) M1011(B,2a), (3) M1080(B,1), (4) 77252(B,NT), (5) 79001(B,12), (6) 79694(B,15). Diffusion was allowed to proceed for 6 days.

with the homologous strain M986 (B, 2a) to determine the duration of protection. Protection was apparent after the third injection of SP-2 (table III) and increased, as serum antibody increased, to $90 \%$ and $100 \%$ protection after the fourth and fifth injections respectively. Some embryos were protected against challenge doses as high as 10000 LD50. Protection was still apparent approximately 5 weeks after the fifth injection or 9 weeks after the initial injection although serum antibody levels had declined. For studies on protection of embryos against challenge with heterologous strains of $N$. meningitidis, only eggs laid during the period of the fourth to ninth weeks inclusive were used.

\section{TABLE III}

Protection of chicken embryos obtained from hens immunised with SP-2 against challenge with the homologous strain of $N$. meningitidis $M 986(B, 2 a)$

\begin{tabular}{cccc}
\hline $\begin{array}{c}\text { Challenge dose } \\
(\times \text { LD50) }\end{array}$ & $\begin{array}{c}\text { Percentage } \\
\text { protection }\end{array}$ & $\begin{array}{c}\text { Period when } \\
\text { eggs were laid }\end{array}$ & $\begin{array}{c}\text { ELISA value* } \\
\text { of sera from hens }\end{array}$ \\
\hline 50 & 67 & $1-7$ days & $0.64-1 \cdot 26$ \\
500 & 50 & $\begin{array}{c}\text { after 3rd } \\
\text { injection }\end{array}$ & \\
5000 & 33 & $\begin{array}{l}1-7 \text { days } \\
\text { after 4th }\end{array}$ & $1 \cdot 26-1 \cdot 60$ \\
100 & 90 & injection & \\
& & $1-7$ days & $1 \cdot 60-1 \cdot 74$ \\
100 & 100 & after 5th & \\
1000 & 75 & injection & \\
10000 & 50 & 32-38 days & $0 \cdot 76-0.64$ \\
100 & 88 & after 5th & \\
500 & 88 & injection & \\
5000 & 75 & &
\end{tabular}

* Ranges of $E_{405}$ values were extrapolated from the antibody response curve for OMV-M986 (B,2a) shown in fig. 1 and represent the 7-day period during which the eggs were collected. 
TABLE IV

Protection of chicken embryos obtained from hens immunised with SP-2 against challenge with serotype $2 a, 2 b$ and $2 c$ strains of $N$. meningitidis

\begin{tabular}{lccc}
\hline $\begin{array}{c}\text { Challenge } \\
\text { strain }\end{array}$ & $\begin{array}{c}\text { Challenge dose } \\
(\times \text { LD50) }\end{array}$ & $\begin{array}{c}\text { Percentage } \\
\text { protection }\end{array}$ & $\begin{array}{c}\text { ELISA value* } \\
\text { of sera from hens }\end{array}$ \\
\hline M986(B,2a) & 100 & 100 & $1 \cdot 74-1 \cdot 56$ \\
M1011(B,2a) & 100 & 100 & $1 \cdot 74-1 \cdot 56$ \\
& 1000 & 100 & \\
$2241(\mathrm{C}, 2 \mathrm{a})$ & 10000 & 75 & \\
& 100 & 50 & $1 \cdot 74-1 \cdot 56$ \\
& 500 & 50 & \\
$78704(\mathrm{C}, 2 \mathrm{a})$ & 5000 & 38 & $1 \cdot 60-1 \cdot 74$ \\
$614(\mathrm{~W} 135,2 \mathrm{a})$ & 150 & 50 & $1 \cdot 26-1 \cdot 60$ \\
$2996(\mathrm{~B}, 2 \mathrm{~b})$ & 200 & 0 & $1 \cdot 74-1 \cdot 56$ \\
& 100 & 100 & \\
$78069(\mathrm{~B}, 2 \mathrm{~b})$ & 100 & 0 & $1 \cdot 60-1 \cdot 74$ \\
S5896(Y,2c) & 100 & 0 & $1 \cdot 74-1 \cdot 56$ \\
\hline
\end{tabular}

* See footnote to table III.

Protection of embryos against different challenge doses of strains belonging to serogroups B, C, Y and W135 and representative of serotypes $2 \mathrm{a}, 2 \mathrm{~b}$, and $2 \mathrm{c}$ is shown in table IV. Excellent protection was obtained against strains M1011 (B, 2a), 614(W135, 2a) and 5896 (Y, 2c). Embryos were partially protected against strains 2241(C, 2a) and 78069 (B, 2b) but were fully susceptible to strains 78704 (C, 2a), and 2996 (B, 2b).

Protection of embryos against heterologous serotypes of $N$. meningitidis is shown

\section{TABLE V}

Protection of chicken embryos obtained from hens immunised with SP-2 against challenge with heterologous serotypes of $N$. meningitidis

\begin{tabular}{|c|c|c|c|c|}
\hline \multirow{2}{*}{$\begin{array}{l}\text { Challenge } \\
\text { strain }\end{array}$} & \multirow{2}{*}{$\begin{array}{c}\text { Challenge } \\
\text { dose } \\
(\times \text { LD } 50)\end{array}$} & \multirow{2}{*}{$\begin{array}{l}\text { Percentage } \\
\text { protection }\end{array}$} & \multicolumn{2}{|c|}{$\begin{array}{l}\text { ELISA value* of sera from } \\
\text { hens in tests with }\end{array}$} \\
\hline & & & Homologous OMV & OMV-M986(B,2a) \\
\hline $\operatorname{M1080}(B, 1)$ & 100 & 63 & $0.48-0.40$ & $1 \cdot 74-1 \cdot 56$ \\
\hline M982(B,9) & 200 & 75 & $0.70-0.60$ & $1.06-0.80$ \\
\hline S3032(B,12) & $\begin{array}{r}125 \\
1250 \\
12500\end{array}$ & $\begin{array}{l}50 \\
38 \\
13\end{array}$ & $0 \cdot 92-1 \cdot 16$ & $1 \cdot 26-1 \cdot 60$ \\
\hline $79001(B, 12)$ & $\begin{array}{r}100 \\
500 \\
5000\end{array}$ & $\begin{array}{l}75 \\
75 \\
50\end{array}$ & $0 \cdot 92-1 \cdot 16$ & $1 \cdot 26-1.60$ \\
\hline $79694(B, 15)$ & $\begin{array}{r}100 \\
500 \\
5000\end{array}$ & $\begin{array}{r}100 \\
75 \\
38\end{array}$ & $0.96-1.04$ & $1.60-1.74$ \\
\hline & 100 & 50 & $0.62-0.52$ & $1.06-0.80$ \\
\hline $77252(\mathrm{~B}, \mathrm{NT})$ & 100 & 0 & $0.24-0.20$ & $1.06-0.80$ \\
\hline
\end{tabular}

* See footnote to table III. 
in table V. Partial protection was demonstrated against strains M1080 (B, 1) and M982 (B, 9) when embryos were challenged with 100 and 200 LD50 of meningococci respectively. Embryos were also protected against two serotype 12 strains, S3032 and 79001; as the challenge dose was increased, protection decreased. Excellent protection was obtained against the serotype 15-related strain 79694 and protection decreased as the challenge dose was increased. Partial protection of embryos was obtained in eggs laid during the eighth week after initial immunisation with SP-2, but embryos from eggs laid during the eighth week and challenged with strain 77252 (B, NT) were fully susceptible.

\section{Discussion}

The chicken embryo is susceptible to meningococcal infection and, after challenge, develops lesions typical of meningococcal infection in man (Buddingh and Polk, 1939; Ueda, Diena and Greenberg, 1969). The specific protection of chicken embryos from hens immunised with formalin-killed group A meningococci (Diena et al., 1976, 1978) suggested that the hen-embryo model might be useful for characterising the immunogenic properties of purified meningococcal antigens.

The basis of the hen-embryo model is the transfer of passive immunity from vaccinated hens to their chickens by the egg (Buxton, 1952; Malkinson, 1965; Kramer and Cho, 1970; Heller, 1975) where a selective concentration of $7 \mathrm{~S} \gamma$-globulin takes place during yolk formation (Malkinson, 1965). The developing embryo absorbs antibodies from the yolk sac during the second half of the incubation period, possibly by absorption from the yolk sac into the vitelline circulation beginning on the eleventh day of incubation and increasing until the end of incubation (Buxton, 1952). These circulating antibodies, in cooperation with the phagocytic system (Karthigasu, Reade and Jenkin, 1965), may protect the embryo against microbial infection.

Previous studies on the protective capacity of serotype 2 vaccines have involved either one or two intramuscular and intraperitoneal injections (Frasch and Robbins, 1978; Craven and Frasch, 1979). In the present study, hens were immunised intravenously because little antibody appears in egg yolks from hens immunised by other routes (Buxton, 1952). A single injection of SP-2 followed by a booster 2 weeks later resulted in an immune response to OMV of the homologous strain M986 (B, 2a) and several heterologous serotypes. However, as found by Benedict, Larson and Nik-Khah (1963), serum antibody levels persisted for only 2 weeks and then declined rapidly. Therefore, to maintain a consistent antibody level during the time needed to collect sufficient eggs for experiments, an extended immunisation schedule of five weekly doses of vaccine was used.

Immunisation with SP-2 resulted in cross-reactivity of sera with several heterologous $N$. meningitidis serotypes. SDS-PAGE revealed that the class $2(41 \mathrm{~K})$ protein was predominant in the immunising antigen with class $1(46 \mathrm{~K})$ and class $5(32 \mathrm{~K})$ proteins also present. Peptide mapping of the OMV from different serotypes has shown that class 1 and 2 proteins of the same or very similar mol. wt contain common peptides (Tsai and Frasch, 1980; Tsai, Frasch and Mocca, 1981). SDS-PAGE of most of the strains that cross-reacted with the hen sera showed class 1 proteins of mol. wt 44-46K. Exceptions were strains 78069 (B, 2b) and S5896 (Y, 2c) that lacked class 1 proteins and strain $2996(\mathrm{~B}, 2 \mathrm{~b})$ that had a class 1 protein of mol. wt $43 \mathrm{~K}$. The 
serotype $2 \mathrm{a}$ and $2 \mathrm{~b}$ strains contained similar amounts of class 2 proteins as judged by intensity of staining after SDS-PAGE. The cross-reactivity of sera with OMV of several serotypes is probably due to the production of antibody to the common peptides of the class 1 or class 2 proteins or both. Some cross-reactivity may be due to common determinants in class 5 proteins.

Antibody produced against the class $2(41 \mathrm{~K})$ protein of strain M986 (B, 2a) should be directed against the specific $2 \mathrm{a}$ determinant and any common antigenic determinants in this protein. Thus, serotype 2 strains containing the $2 \mathrm{a}$ determinant should give the highest ELISA values and this proved to be the case. The lowest ELISA values were obtained with the serotype 2b strains 78069 and 2996 and the serotype 2c strain S5896. These values may represent a measure of the cross-reactive antibody to the common type 2 peptides shared by these strains.

Several studies have shown a correlation between serotype 2 and disease due to groups B, C, Y and W135 meningococci (Gold et al., 1971; Frasch and Chapman, 1973; Munford et al., 1975; Jones and Tobin, 1976; Frasch, 1977; Frasch and Friedman, 1977; Ashton et al., 1980; Poolman et al., 1980; DeMaeyer et al., 1981). These observations form the basis for the selection of serotype 2 as a potential vaccine. Poolman et al. (1980) divided serotype 2 disease-associated meningococci into serotypes $2 \mathrm{a}, 2 \mathrm{~b}$ and $2 \mathrm{c}$. Serotype $2 \mathrm{c}$ appears to be restricted to group $\mathrm{Y}$ strains (Poolman et al., 1980) but serotype 2a and, particularly, serotype $2 \mathrm{~b}$ are associated with group B disease (Ashton et al., 1980; Poolman et al., 1980). Therefore, it is important that a group B vaccine containing the type 2 protein should provide protection against infection with serotypes $2 \mathrm{a}$ and $2 \mathrm{~b}$.

Embryos from hens immunised with protein extracted from serotype 2a meningococci were protected against challenge with serotype 2 a strains of groups B and W135, confirming results obtained with other experimental models (Frasch and Robbins, 1978; Craven and Frasch, 1979). However, they were only partially protected against one group $\mathrm{C}$ serotype 2a strain and fully susceptible to another such strain, despite high levels of antibody to OMV of this strain in hen serum, yolks and embryo plasma. Similar differences in protection against group $\mathrm{C}$ serotype 2 meningococci have been observed in the mouse bacteraemia model and it has been suggested that differences in capsule size may account for these observations (Craven and Frasch, 1979). The chicken embryo and mouse bacteraemia models probably measure different protection mechanisms, namely phagocytosis and the serum bactericidal effect, but penetration of capsular polysaccharide by antibody must occur in both models. Therefore, the lack of protection against strain 78704 may be due to the inability of antibody to penetrate the capsule.

Surprisingly, there was no and only partial protection against challenge with group B, serotype 2b strains 2996 and 78069 respectively. The reason for the limited protection against the serotype $2 \mathrm{~b}$ strains is unknown, but possible mechanisms include the exclusion of antibody by capsular polysaccharide, penetration of antibody through the polysaccharide but failure of the antibody to reach common peptides that are hydrophobic and probably embedded in the outer membrane (Tsai and Frasch, 1980; Tsai et al., 1981), and failure of the serotype 2a protein to generate antibody against the $2 \mathrm{~b}$ determinant. Such antibody may be required to provide maximum protection against infection with serotype $2 \mathrm{~b}$ meningococci.

Embryos were partially protected against challenge with the heterologous 
serotypes $1,9,12$ and 15 of $N$. meningitidis. Protection against meningococcal serotypes 1 and 9 has also been demonstrated in other animal models (Frasch and Robbins, 1978; Craven and Frasch, 1979), but protection against serotypes 12 and 15 has not been reported previously. The serotype $1,9,12$ and 15 strains were shown to have class 1 proteins of similar mol. wt by SDS-PAGE and protection may result from antibody produced against common peptides in the class 1 proteins of these organisms.

The lack of protection against strain $77252(\mathrm{~B}, \mathrm{NT})$ correlated with the absence of antibody in hen sera and yolks and plasma of embryos. This strain probably contained immunologically unrelated class 1 and class 5 proteins. Embryos challenged with strain 77252 were collected during the eighth week of the study, when less antibody against OMV of strain M986 was present in hen sera. However, it is unlikely that protection would be found in embryos collected at any time, because no cross-reactive antibody could be detected during the study. Moreover, good protection was still apparent with the homologous strain M986 (B, 2a) during the ninth week of the study.

Previous studies have shown that the R-type LPS of $N$. gonorrhoeae is immunogenic in hens and that embryos obtained from immunised hens are protected against challenge with homologous and heterologous strains of $N$. gonorrhoeae (Diena et al., $1978 a$ and $b$; Wallace $e t a l$., 1978). SP-2 contained $<10 \%$ of LPS and antibodies to common LPS determinants might be responsible for the protection. However, no antibody to purified LPS was detected in sera of hens immunised with SP-2 or with 10 $\mu \mathrm{g}$ or $100 \mu \mathrm{g}$ of LPS for 5 consecutive weeks (unpublished observations). The differences in immunogenicity of the gonococcal and meningococcal LPS may be related to the composition and subsequent structural features of oligosaccharides in the LPS. It is unlikely, therefore, that protection of embryos was due to antibody to LPS. Frasch and Robbins (1978) were unable to detect antibody to LPS from strain M986 in serum of guinea pigs immunised with serotype 2 protein containing similar amounts of LPS.

The frequency of group B disease, especially in children, has emphasised the need for the development of a meningococcal vaccine to help control group $B$ disease. The serotype 2 protein extracted from strain M986 (B, 2a) is protective in animal models (Frasch and Robbins, 1978; Craven and Frasch, 1979) but does not appear to be a satisfactory immunogen in humans (Zollinger et al., 1978; Frasch, 1979). However, a more soluble protein, or protein complexed with group B polysaccharide appear to be more promising as vaccines (Zollinger et al., 1979; Frasch et al., 1982; Frasch and Peppler, 1982; Peppler and Frasch, 1982). On the basis of recent observations that serotype $2 \mathrm{~b}$ meningococci are more prominently associated with group $\mathrm{B}$ disease than are serotype 2a meningococci (Ashton et al., 1980; Poolman et al., 1980), and the results of the present study showing that protein extracted from strain M986 provided limited protection against serotype $2 b$ meningococci, it seems important that $a$ complex of group B polysaccharide and outer membrane proteins extracted from both serotype $2 \mathrm{a}$ and $2 \mathrm{~b}$ meningococci should be investigated as a vaccine that would provide the broadest protection against serotype 2 meningococci. Further studies involving other animal models described by Frasch and Robbins (1978), Craven and Frasch (1979) and Huet and Suire (1981) are required to confirm these studies.

Although considerable caution in interpreting results of animal models is necessary, our studies suggest that a careful evaluation of class 1 and, possibly, class 5 
proteins that are included in vaccines should be performed to determine their possible role in providing protection against group B meningococci of other serotypes (Holten, 1979) including non-typable strains that appear to be more prevalent during endemic periods of disease (Broud, Griffiss and Baker, 1979; Jones and Eldridge, 1981).

\section{REFERENCES}

Ashton, F. E., Ryan, A. AND DiENA, B. B. 1980. Improved antiserum agar method for the serogroup differentiation of Neisseria meningitidis $\mathrm{Y}$ and W135. Canadian Journal of Microbiology, 26, 630-632.

Ashton, F. E., Ryan, A., Diena, B. B. ANd Frasch, C. E. 1979. Evaluation of the antiserum agar method for the serogroup identification of Neisseria meningitidis. Canadian Journal of Microbiology, 25, 784-787.

Ashton, F. E., Ryan, A., Diena, B. B., MacKenzie, A. M. R. and Chan, F. 1980. Serotypes among Neisseria meningitidis serogroups B and $\mathrm{C}$ strains isolated in Canada. Canadian Journal of Microbiology, 26, 1480-1488.

Benedict, A. A., LaRson, C. AND NiK-KHAH, H. 1963. Synthesis of chicken antibodies of high and low molecular weight. Science, 139, 1302-1303.

Bovre, K., Holten, E., Vik-Mo, H., Brondbo, A., Bratlid, D., BJark, P. And Moe, P. J. 1977. Neisseria meningitidis infections in northern Norway: an epidemic in 1974-1975 due mainly to group B organisms. Journal of Infectious Diseases, 135, 669-672.

BROUD, D. D., GrIFFISS, J. M. AND BAKER, C. J. 1979. Heterogeneity of serotypes of Neisseria meningitidis that cause endemic disease. Journal of Infectious Diseases, 140, 465-470.

Buddingh, G. J. AND Polk, A. D. 1939. Experimental meningococcus infection of the chick embryo. Journal of Experimental Medicine, 70, 485-498.

BuxTON, A. 1952. On the transference of bacterial antibodies from the hen to the chick. Journal of General Microbiology, 7, 268-286.

Craven, D. E. AND Frasch, C. E. 1979. Protection against group B meningococcal disease: evaluation of serotype 2 protein vaccines in a mouse bacteremia model. Infection and Immunity, 26, 110-117.

Craven, D. E., Frasch, C. E., Robbins, J. R. and Feldman, H. A. 1978 . Serogroup identification of Neisseria meningitidis: comparison of an antiserum agar method with bacterial slide agglutination. Journal of Clinical Microbiology, 7, 410-414.

DeMaeyer, S., Seba, J. S.-M. and Reginster, G. 1981. Epidemiology of meningococcal meningitis in Belgium. Journal of Infection, 3(Suppl.), 63-70.

Diena, B. B., Ashton, F. E., Ryan, A., Wallace, R. And Perry, M. B. 1978a. Immunizing properties of gonococcal (R-type) lipopolysaccharide in the chicken embryo animal model. In Immunobiology of Neisseria gonorrhoeae, edited by G. F. Brooks et al. American Society for Microbiology, Washington, DC. pp. 319-323.

Diena, B. B., Ashton, F. E., Ryan, A., Wallace, R. and Perry, M. B. 1978b. The lipopolysaccharide (R-type) as a common antigen of Neisseria gonorrhoeae. I. Immunizing properties. Canadian Journal of Microbiology, 24, 117-123.

Diena, B. B., Lavergne, G., Ryan, A., Ashton, F. E. and Wallace, R. 1976. Transmission of immunity to Neisseria gonorrhoeae from vaccinated hens to embryos. Immunological Communications, 5, 69-73.

Farries, J. S., Dickson, W., Greenwood, E., Malhotra, T. R., Abbott, J. D. and Jones, D. M. 1975. Meningococcal infections in Bolton 1971-1974. Lancet, 2, 118-120.

FrasCH, C. E. 1977. Role of protein serotype antigens in protection against disease due to Neisseria meningitidis. Journal of Infectious Diseases, 136, Suppl., 584-590.

FrasCH, C. E. 1979. Noncapsular surface antigens of Neisseria meningitidis. In Seminars in infectious disease, vol. 2, edited by L. Weinstein and B. N. Fields, Stratton, New York, pp. 304-337.

Frasch, C. E. AND Chapman, S. S. 1972a. Classification of Neisseria meningitidis group B into distinct serotypes. I. Serological typing by a microbactericidal method. Infection and Immunity, 5, 98-102. 
Frasch, C. E. ANd Chapman, S. S. 1972b. Classification of Neisseria meningitidis group B into distinct serotypes. II. Extraction of type-specific antigens for serotyping by precipitin techniques. Infection and Immunity, 6, 127-133.

Frasch, C. E. AND Chapman, S. S. 1973. Classification of Neisseria meningitidis group B into distinct serotypes. III. Application of a new bactericidal-inhibition technique to distribution of serotypes among cases and carriers. Journal of Infectious Diseases, 127, 149-154.

Frasch, C. E. and Friedman, G. L. 1977. Identification d'un serotype meningococcique associé à la maladie et commun aux meningocoques des groups $\mathrm{B}, \mathrm{C}, \mathrm{Y}$ et W135. Medecine Tropicale, 37, 155-159.

Frasch, C. E. AND Gotschlich, E. C. 1974. An outer membrane protein of Neisseria meningitidis group B responsible for serotype specificity. Journal of Experimental Medicine, 140, 87-104.

Frasch, C. E. AND PePpler, M. S. 1982. Protection against group B Neisseria meningitidis disease: preparation of soluble protein and protein-polysaccharide immunogens. Infection and Immunity, 37, 271-280.

Frasch, C. E., Peppler, M. S., Cate, T. R. and Zahradnick, J. M. 1982. Immunogenicity and clinical evaluation of group B Neisseria meningitidis outer membrane protein vaccines. In Seminars in infectious disease, edited by J. B. Robbins, J. C. Hill and J. Sadoff, Thieme-Stratton, New York, pp. 263-267.

FrasCH, C. E. AND RobBins, J. D. 1978. Protection against group B meningococcal disease. III. Immunogenicity of serotype 2 vaccines and specificity of protection in a guinea pig model. Journal of Experimental Medicine, 147, 629-644.

Gold, R., Winkelhake, J. L., Mars, R. S. AND ARTENSTEIN, M. S. 1971. Identification of an epidemic strain of group C Neisseria meningitidis by bactericidal serotyping. Journal of Infectious Diseases, 124, 593-597.

Heller, E. D. 1975. The immune response of hens to multiple Escherichia coli injections and transfer of immunoglobulins to the egg and hatched chick. Research in Veterinary Science, $18,117-120$.

Holten, E. 1979. Serotypes of Neisseria meningitidis isolated from patients in Norway during the first six months of 1978. Journal of Clinical Microbiology, 9, 186-188.

HUET, M. AND SuIRE, A. 1981. Un modèle animal pour l'activité des vaccins polyosidiques méningococciques. Journal of Biological Standardization, 9, 67-74.

JoNes, D. M. AND EldRIDGE, J. 1981. Meningococcal disease in England and Wales. 1978-79-a change in the serotype pattern. Journal of Infection, 3, 134-139.

JoNes, D. M. AND TOBIN, B. M. 1976. Serotypes of group B meningococci. Journal of Clinical Pathology, 29, 746-748.

Karthigasu, K., Reade, P. C. And Jenkin, C. R. 1965. The functional development of the reticulo-endothelial system. III. The bactericidal capacity of fixed macrophages of foetal and neonatal chicks and rats. Immunology, 9, 67-73.

Kellogg, D. S., Peacock, W. L., Deacon, W. E., Brown, L. and Pirkle, C. I. 1963. Neisseria gonorrhoeae. I. Virulence genetically linked to clonal variation. Journal of Bacteriology, 85, 1274-1279.

KRAMER, T. T. AND CHO, H. C. 1970. Transfer of immunoglobulins and antibodies in the hen's egg. Immunology, 19, 157-167.

Lowry, O. H., Rosebrough, N. J., Farr, A. L. AND Randall, R. J. 1951. Protein measurement with the Folin phenol reagent. Journal of Biological Chemistry, 193, 265-275.

Malkinson, M. 1965. The transmission of passive immunity to Escherichia coli from mother to young in the domestic fowl (Gallus domesticus). Immunology, 9, 311-317.

Munford, R. S., Patton, C. M. and Gorman, G. W. 1975. Epidemiologic studies of serotype antigens common to groups B and C Neisseria meningitidis. Journal of Infectious Diseases, 131, 286-290.

Munoz, J. 1971. Double diffusion in plates. In Methods in immunology and immunochemistry, vol III, edited by C. A. Williams and M. W. Chase, Academic Press, New York, pp. $146-159$. 
PepPleR, M. S. AND Frasch, C. E. 1982. Protection against group B Neisseria meningitidis disease: effect of serogroup B polysaccharide and polymyxin B on immunogenicity of serotype protein preparations. Infection and Immunity, 37, 264-270.

PoOlman, J. T., Hopman, C. T. P. AND ZANEN, H. C. 1980. Immunochemical characterization of Neisseria meningitidis serotype antigens by immunodiffusion and SDS-polyacrylamide gel electrophoresis immunoperoxidase techniques and the distribution of serotypes among cases and carriers. Journal of General Microbiology, 116, 465-473.

The Meningococcal Disease Surveillance Group. 1976. Analysis of endemic meningococcal disease by serogroup and evaluation of chemoprophylaxis. Journal of Infectious Diseases, 134, 201-204.

TSAI, C.-M. AND FraSCH, C. E. 1980. Chemical analysis of major outer membrane proteins of Neisseria meningitidis: comparison of serotypes 2 and 11. Journal of Bacteriology, 141, 169-176.

TSaI, C.-M., Frasch, C. E. AND Mocca, L. F. 1981. Five structural classes of major outer membrane proteins in Neisseria meningitidis. Journal of Bacteriology, 146, 69-78.

Ueda, K., Diena, B. B. AND GreEnberg, L. 1969. The chick embryo neutralization test in the assay of meningococcal antibody. I. Infection of the embryo with Neisseria meningitidis. Bulletin of the World Health Organization, 40, 235-240.

VARUgheSE, P. AND ACRES, S. 1980. Meningococcal disease in Canada 1921-1979. Canada Diseases Weekly Report., 6, 243.

Wallace, R., Ashton, F. E., Ryan, A., Diena, B. B., Malysheff, C. and Perry, M. B. 1978. The lipopolysaccharide (R-type) as a common antigen of Neisseria gonorrhoeae. II. Use of hen antiserum to gonococcal lipopolysaccharide in a rapid slide test for the identification of $N$. gonorrhoeae from primary isolates and secondary cultures. Canadian Journal of Microbiology, 24, 124-128.

Wyle, F. A., Artenstein, M. S., Brandt, B. L., Tramont, E. C., Kasper, D. L., Altieri, P. L., BERMAN, S. L. AND LowENTHAL, J. P. 1972. Immunologic response of man to group B meningococcal polysaccharide vaccines. Journal of Infectious Diseases, 126, 514-522.

ZOLLINGER, W. D. AND MANDRELL, R. E. 1977. Outer membrane proteins and lipopolysaccharide serotyping of Neisseria meningitidis by inhibition of a solid-phase radioimmunoassay. Infection and Immunity, 18, 424-433.

Zollinger, W. D., Mandrell, R. E., Altieri, P., Berman, S., Lowenthal, J. ANd Artenstein, M. S. 1978. Safety and immunogenicity of a Neisseria meningitidis type 2 protein vaccine in animals and humans. Journal of Infectious Diseases, 137, 728-739.

Zollinger, W. D., Mandrell, R. E., Griffiss, J. M., Altieri, P. And Berman, S. 1979. Complex of meningococcal group B polysaccharide and type 2 outer membrane protein immunogenic in man. Journal of Clinical Investigation, 63, 836-848. 